\title{
Development of Bureaucracy in Excellent Service: A Case Study of Licensing Services in Pinrang Regency
}

\author{
Badu Ahmad ${ }^{1}$, Adnan Nasution ${ }^{2}$ \\ \{badu@unhas.ac.id ${ }^{1}$, adnan_ugm@yahoo.com ${ }^{2}$ \}
}

Department of Administrative Sciences, Universitas Hasanuddin, Jl. Perintis Kemerdekaan KM 10.

Makassar-Indonesia ${ }^{1,2}$

\begin{abstract}
This study aims to conclusively analyze the development of competence of government officials in realizing excellent service in the field of licensing in Pinrang Regency. This study uses a qualitative approach and descriptive method to describe and analyze research objectives. The determination of informants was carried out randomly by 20 people who understood the substance of the problem under study. Data collection techniques using in-depth interviews and focus group discussions. The results showed that the distribution of employees based on personal skills and competence in the Office of Investment and One Stop Integrated Services was not in line with the results of the evaluation and analysis of positions. This is one of the inhibiting factors in realizing excellent service in the permit sector. The competency dimensions according to Spancer and Spencer [1] have not yet been fully developed to improve the competence of local government officials. The Pinrang Regency Government makes policies on developing the competency of state civil servants and non-state civil servants in the form of: Education and training in accordance with work needs, functional technical guidance in investment and licensing services, technical human relations technical guidance, online technical guidance services, guidance strengthening spiritual, social and emotional intelligence so that service officers avoid abuse of authority and responsibility as a community service.
\end{abstract}

Keywords: Development of Competence; Excellent Service; Public Service

\section{Introduction}

The development of human resources in the public sector is the key to the success of the goals of government and development. In the context of regional autonomy, improving performance is the benchmark of any government apparatus in carrying out its authority. According to Enceng, Lestyodono [2] Local government officials should adhere to the customer-driven paradigm, namely as a community service. In realizing excellent service coveted by the people of a nation, it is strongly influenced by the competent and professional apparatus resources in carrying out their main tasks and functions. The problem faced by local governments is the limitations of the apparatus from the quality aspect in carrying out their main tasks and functions. Efforts to address this problem the Pinrang District Government is required to develop apparatus competencies as part of bureaucratic reform, especially to optimize the utilization of local government apparatus in serving and meeting various community needs.

The requirement to improve the competency of government officials is to provide opportunities and opportunities to improve education to a higher level and develop skills and expertise according to the development of science and technology and the demands of work. 
This is in line with Gibson's view [3] Thoha [4] that one's ability, the maturity of the government apparatus is related to the knowledge and skills obtained from education, training, and experience..

\section{Research Method}

In this study, using a qualitative approach to describe the development of apparatus competencies in realizing excellent service. The research locus is the Office of Investment and Integrated One-Stop Services of Pinrang Regency, South Sulawesi Province. Determination of informants in the study was carried out by purposive sampling in the field with the criteria that the informants were believed to have sufficient and valid data and information. The data collection techniques in this study are (1) Observation; (2) Independent interview and Focus Group Discussion (FGD), (3) Documentation. The data analysis technique used in this study is an interactive model from Miles and Huberman, which includes three stages, namely data reduction, data presentation, and conclusion or data verification.

\section{Result And Discussion}

\subsection{Competency Perspective}

Enceng [2] competence is defined as knowledge, skills and abilities that are mastered by someone who has become a part of him so that he can perform cognitive, affective, and psychomotor behaviours as well as possible. Whereas Sofo [5] suggests that competency does not only content knowledge, skills and attitudes but most importantly is the application of knowledge and skills and attitudes needed by the job. Furthermore, Harmon and Mayer [6] suggest that the capacity of the government apparatus is used to support the democratic and accountable governance management process.

Spencer and Spancer [1] competency Apparatus resources are formed by five things, namely 1 motives, character, self-concept (central competence), knowledge, and skills (individual competencies are the intent). Central competencies that encourage the use of knowledge and skills possessed. Furthermore, Robbins [7] revealed that one's competence is closely related to intelligence possessed. There are two competencies, namely personal competence, including self-regulation, self-awareness, and motivation. While social competence includes empathy and social skills. Intellectual competence and physical abilities are individual capacities in carrying out their work. According to Enceng [2] the acquisition of employee mentality or regional officials with behavioural standards that can bring bureaucratic capability, not only proactive, cooperative but expected to be adaptive and responsive so that public organizations can follow changes and demands of society.

\subsection{Competence Development of Bureaucratic Apparatus Towards Excellent Service}

Increasing the competency of local government apparatus as an effort to improve the quality of public service delivery as the main condition in realizing excellent service is a key indicator of the successful implementation of local government activities. Every local government apparatus has sincerity, openness, discipline, ethics and morality, thinking modern, professional, 
and superior work culture. According to Sulistiyani and Keban [8], the development of apparatus resources that are relevant to good governance and improved service performance include mental-spiritual development to strengthen personality, honesty, sense of responsibility, friendship, and loyalty. Development of employee behaviour includes the enforcement of discipline, high responsiveness to change. While the development of capabilities, skills and skills is intended to achieve professionalism, work efficiency, work effectiveness, and productivity. This is in line with Wodruffe's [9] view of the competency dimension to realize excellent service including communication skills, sensitivity and awareness outside the organization, tenacity, creativity, risk-taking, initiative, tolerance to stress, adaptability.

According to Sudarmanto [10], individual competencies can boost employee performance in carrying out tasks that ultimately encourage organizational performance. Competencies that must be possessed by individuals include integrity and honesty, control and self-awareness, selfdevelopment, achievement orientation, self-confidence, organizational commitment, initiative and proactive, creative and innovation, cognitive abilities, ability to manage change, excellent service orientation, leadership, ability managerial, building cooperation, managing conflict. According to Covey [11], Cooper \& Sawaf [12], Zwell [13] integrity and honesty competencies are the necessary capital in climbing career ladders, producing collaborative activities and high levels of achievement, unifying words with actions and obeying actions against what promised. To be a successful leader, integrity and honesty are one of the important prerequisites that must be owned. According to Ress \& McBain [14], Future leaders' success is determined by emotional intelligence, including self-awareness, self-motivation, and empathy and interpersonal sensitivity. Emotional intelligence gives birth to the ability to manage feelings and emotions, be sensitive to the needs of others, the balance between motives and ethical behaviour and responsibility.

Competency development Human resources such as (a) input-based competencies, emphasize manager-fit strategies through the appointment of employees for the organization as a whole in the form of human resource integration. (b) transformational competence; emphasizing innovation and utilization of entrepreneurship through the process of forming and disseminating employee behaviour based on creativity, cooperation and mutual trust. (c) Output-based competencies; more emphasis on higher involvement of employees through a positive learning process, building a good reputation and positive relationships with stakeholders.

Service-oriented human resource competencies have an impact on increasing employee and community job satisfaction. Human resources who are satisfied with their performance will always try their best to provide services that satisfy the needs and desires of the community. Competence and Professionalism Government apparatus emphasizes the ability, expertise and skills of government officials in providing public services that are democratic, responsive, transparent, accountable, efficient and effective. The professionalism of the government apparatus includes the commitment and innovation carried out by employees in supporting the implementation of work efficiently and effectively.

\subsection{Excellent Service}

According to Adisasmita [15], the mission and purpose of public sector organizations are to strive to give satisfaction to the public in interest through excellent public services and maintain public trust / c. In line with Rahmayanti's opinion [16], excellent service is an excellent service and exceeding customer expectations. Whereas Wiranta [17] said that the impression of the Indonesian people is less satisfied with public services that are complicated, old, expensive, less 
accurate. Today the community demands excellent service, which is quick-easy-cheap-accurate. Excellent public service requires a competent and professional government apparatus in carrying out their primary duties and functions. Moenir [18] emphasized that every employee should have adequate abilities and skills in carrying out work well and quickly in meeting the needs of the community. The regional government apparatus is competent in its field of duty, an appropriate condition for the implementation of an efficient and effective government. The resources of the government apparatus must have a work ethic such as diligence, hard work, high discipline, restraint, perseverance, resilience, which is very supportive for the realization of the ministry of rhyme. Ahmad [19] argued that apparatus competence and professionalism were not the only way to create excellent service because other alternatives were creating systems and simplifying efficient work procedures, clarity and certainty of costs and times of service, security and comfort, openness, fairness, accuracy of results, ease of access, complete facilities and infrastructure, and responsiveness to complaints and needs of the community.

Law Number 25 the Year 2009, the essence of public service is the provision of excellent service to the community as a manifestation of the obligation of government officials as servants of the state and society. This, confirmed by Ahmad [20] excellent service is an excellent service in fulfilling needs by the sense and subjective values of the community concerned. In the Decree of the Minister of Administrative Reform Number 63 of 2004, it is stated that service providers must fulfil several principles and operational standards of service procedures and be published as a guarantee of certainty for service recipients. The service standard is a measure that is standardized in the implementation of public services and must be adhered to by the service provider and recipient.

Competence as part of the professionalism of government officials as a condition for realizing good governance in public services [21]. Competence emphasizes intellectual competence including the ability, skills and expertise of government officials in providing responsive, transparent, effective and efficient services. Competent and professional local government apparatus can work effectively if supported by the suitability of the educational background with the workload that is their responsibility. The self-potential and ability of the regional government apparatus are reflected in loyalty, discipline, innovation, productivity, and creativity. The regional government is upholding the values of honesty, ethics, and openness in carrying out the duties and functions of services that are free from nuances of corruption, collusion and hassle. The standard of competence and professionalism of the government apparatus is accountability in serving the community. Also, regulation is needed as a standard that regulates the behaviour of service personnel to act professionally in carrying out their main tasks and functions.

Based on secondary data on the condition of the state civil apparatus based on the level of education in the Pinrang District One-Stop Investment Service and Integrated Services Office, of 33 state civil apparatus 28 (84.84\% have high education, and only 5 people $(15.16 \%)$. School Education Above and equivalent, the data shows that the level of master, bachelor and diploma education possessed by the government apparatus is quite potential to develop competence and professionalism according to the demands and needs of the work, supported by interviews with $\mathrm{AM}$ as the head of office "that the level of Masters education, bachelor, and diploma owned by licensing service officers contribute to the development of competencies and professionalism in carrying out the main tasks and functions of licensing services. As the leader of the organization, always encourages and encourages employees to learn according to the development of science and technology information. Only employees who have talent, enthusiasm for learning to develop their competencies can follow any changes in policies, work systems, and procedures, as well as community demands "(interview, 9 July 2019). This is in Senge's [22] view that 
employees who are learners play an urgent, vital, and strategic role in increasing the capacity of government organizations so that the apparatus within them has equitable abilities by the demands of change and work systems in a sustainable manner.

Whereas the results of the H.N interview in relation to employee competency in the licensing service section said "employees placed in service units are carried out selectively and based on criteria; applications that are on the computer, have social intelligence in the form, friendly, and caring attitude to the community, time and work discipline. Also, to create comfort for service and visitor officers, service units are equipped with air conditioning, bureau seats, dispensers, waiting rooms, reading materials, TV, breastfeeding rooms for mothers who have babies, wheelchairs for those in need. " Furthermore, the results of the M.N interview showed that the complete facilities and infrastructure of services we're able to improve the professionalism and performance of licensing services. Even the one-stop integrated service unit gets rank III National in excellent service in the licensing field." (Interview, 10 July 2019).

The strategy carried out by the Regional Government of Pinrang Regency in South Sulawesi in improving the competency of regional government officials contained in the policy of developing regional apparatus refers to the dimensions of competence according to Spencer and Spencer [1] that competence is formed by (1) motives namely the encouragement or desire of the government apparatus to improve competencies according to job requirements, (2) traits, namely talent and self potential of an employee developed through teamwork, (3) self concept, namely the ability of the apparatus to channel ideas, ideas brilliant to realize excellent service, (4) knowledge, namely competence development through the development of education to a higher level, (5) skills (skills) that are prominent individual competencies so that in carrying out the main tasks the service function is more effective and efficient. Based on the results of A.Y.R's interview that the Pinrang District Government's policy on the development of apparatus from various dimensions was mentioned "that the development of apparatus competencies from the dimensions of knowledge and skills is carried out through education and training according to job requirements, technical guidance on licensing services and investment. While the dimensions of motives, character, self-concept, it is challenging to develop the programmatically because it collides with the standard and rigid aspects of the rules. Besides that, employee rotation tends to pay less attention to the suitability between the competencies possessed and the main tasks and functions so that it influences the decline in employee performance. Also, the Regional Government develops competence through strengthening spiritual, social, and emotional intelligence, so that service personnel are protected from extortion, corruption, collusion and nepotism. (interview, 11 July 2019. While the results of the D.M interview that one of the factors inhibiting the development of the competency of government officials in the Investment and Integrated One-Stop Service Office is budget constraints.

\section{Conclusion}

The results of the study show that the distribution of employees based on competency to parts and sub-sections in the Investment Office and the One-Stop Integrated Service 
Environment is not by the results of evaluation and job analysis. This is one of the inhibiting factors in realizing excellent service in the field of licensing. The dimensions of competency, according to Spencer and Spencer [1] cannot be fully developed to improve the competence of local government officials. The Pinrang District Government makes a policy to develop the competency of state civil servants and regional honorary employees in the form of Education and training after work needs, functional technical guidance in the field of investment and licensing services, human relations technical guidance, online service technical guidance, guidance for strengthening spiritual intelligence, social, and emotional so that service personnel avoid abuse of authority and responsibility as community service. However, there are several obstacles in developing the competency of regional government officials, among others; limitations of the Regional Budget, the low incentive of temporary employees who have excellent morale

\section{References}

[1] Spencer, L. M. J., Spencer, S. M.:Competence at Work. Models for Superior Performance, New York: John Willey \& Sons, (1993)

[2] Enceng L., Purwaningdyah.: Peningkatan Kompetensi Aparatur Pemerintah Daerah Dalam Mewujudkan Good Governance, “Jurnal Kebijakan dan Manajemen PNS, zv. 2, \%1. vyd.1, pp. 33-43 (2008)

[3] Gibson, L. J., Ivancevich, J. M., and Donnely, J. H.: Organisasi-Perilaku, Struktur Proses., Jakarta: Erlangga (1986)

[4] Toha, M. Pembinaan Organisasi: Proses Diagnosa dan Intervensi, Jakarta: PT Grafindo Persada (1988)

[5] Sofo, F.: Human Resource Development, Perspective, Role and Practice Choice. Business and Professional Publishing, Warriewood: NWS (1999)

[6] Harmon, M., Mayer, R. T.: Organization Theory for Public Administration, Toronto: Little Brown And Co (1986)

[7] Robbins, S. P.: Organization Behavior, Concept Controversies, Application, New Jersey: Frentice Hall International. Inc. 9th Edition (2001)

[8] Sulistyani, A., Keban, T.: Memahami Good Governance: Dalam Perspektif Sumber Daya Manusia, Yogyakarta: Gava Media (2004)

[9] Woodruffe, C.: Assessment Centres, Identifying and Development Comperence. Second Edition, London: Institute of Personal Management (IPM) (1993)

[10] Sudarmanto.: Kinerja dan Pengembangan Kompetensi Sumber Daya Manusia: Teori, Dimensi Pengukuran, dan Implementasi Dalam Organisasi, Yogyakarta: Pustaka Pelajar (2009)

[11] Covey, S. R.: The 7 Habits of Highly Effective People, Binarupa Aksara (1997)

[12] Cooper, R. K., AymanSawaf.: Kecerdasan Emosional Dalam Kepemimpinan dan Organisasi, Jakarta: Pustaka Utama (2001)

[13] Zwell, M. : Creating A Culture of Competence, New York: John Wiley \& Sons (2000)

[14] Ress, D., Richard, M.: People Management: Teori \& Strategi (Peluang dan Tantangan), Jakarta: Kencana (2007) 
[15] Adisasmita, R.: Manajemen Perintahan Daerah, Yogyakarta: Graha Ilmu (2011)

[16] Rahmayanti, N. : Manajemen Pelayanan Prima: Mencegah Pembelotan dan membangun Customer Loyalty, Yogyakarta: Graha Ilmu (2010)

[17] Wiranta, D. N.: Penguatan Peran Pemerintah Daerah Dalam Mendorong Pertumbuhan Ekonomi Lokal: Peluang dan Tantangan Masyarakat Ekonomi Asean (MEA) 2015,“ Jurnal Lingkar Widyaiswara, zv. 2, \%1. vyd.3, pp. 33-50 (2015)

[18] Moenir, H. A.: Manajemen Pelayanan Umum di Indonesia, Jakarta: Bumi Aksara (2006.)

[19] Ahmad, B.: Pelayanan Publik: Teori dan Praktek, Bandung: Manggu (2017)

[20] Ahmad, B. .: Service Innovation in Local Government: Analysis of Business Information Service in South Sulawesi Province, Indonesia.," Mediterranean Journal of Social Sciences, zv. 9, \%1. vyd.3, pp. 217-224 (2018)

[21] Tjokrowinoto, M.: Pembangunan, Dilema dan Tantangan, Yogyakata: Pustaka Pelajar, (1996)

[22] Senge, P. M.: The Art and Practice of Learning Organization, London : Century, 1990.

[23] Francesco, Human Resource Development, Perspective, Role and Practice Choice. 